\title{
REVIEW
}

\section{Squamous cell carcinoma of thyroid: a unique type of cancer in World Health Organization Classification}

\author{
Alfred King-yin Lam \\ School of Medicine, Griffith University, Gold Coast, Australia \\ Correspondence should be addressed to A K Lam: a.lam@griffith.edu.au
}

\begin{abstract}
The aim is to review the features of 117 primary squamous cell carcinomas of thyroid which meet the histological criteria of the World Health Organization classification of endocrine tumours. The carcinomas occur in 83 women and 34 men (female to male ratio is 2.4 to 1 ) and with median age at presentation of 64 . Half of these squamous cell carcinomas of thyroid were moderately differentiated. PAX-8 protein is a sensitive marker for confirming the thyroid origin of the carcinoma. The carcinoma is also positive for p63, p40, cytokeratins 5/6, 7,19 and negative for cytokeratins 20 and 10/13. P53 overexpression is common. The most important differential diagnosis is direct infiltration or metastatic involvement by squamous cell carcinoma from other organs. Limited mutation analysis revealed BRAF mutation in some squamous cell carcinomas of the thyroid. The genetic profile appears to be different from anaplastic thyroid carcinomas. Primary squamous cell carcinoma of thyroid had lymph node involvement in $59 \%$ and distant metastases in $26 \%$. The median survival of the patients was 8 months. Curative surgery offers the best survival for the patients with the carcinoma. To conclude, primary squamous cell carcinoma of the thyroid gland has distinctive clinical, pathological and molecular profiles. It is important to recognize this unique variant of thyroid carcinoma for possible curative surgical resection and to do more genomic works on the entity to uncover the molecular pathogenesis.
\end{abstract}

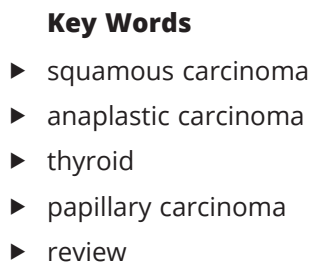

Endocrine-Related Cancer (2020) 27, R177-R192

\section{Introduction}

Squamous cell carcinoma is a rare tumour of the thyroid gland. In the second edition of the World Health Organization (WHO) Histological Typing of Thyroid Tumours published in 1988, squamous cell carcinoma of the thyroid gland was briefly listed in 'Other carcinomas' in the category of malignant epithelial tumours (Hedinger et al. 1993). The entity first becomes a separate entity of thyroid tumour in third edition of the WHO classification of tumours published in 2004 (Lam $\&$ Sakamoto 2004). In the current (4th edition) WHO classification of endocrine tumours published in 2017, squamous cell carcinoma remains as a separate entity of thyroid carcinoma (Carcangiu et al. 2017). However, there is no great difference in the content of the chapters on this entity between the two editions of WHO book despite 13 years in between. It is worth noting that there is a proposed developmental relationship between anaplastic carcinoma and squamous cell carcinoma (Lam $\&$ Saremi 2017). Studies in the recent years have revealed more details on the clinicopathological, genomic and 
therapeutic characteristics of anaplastic thyroid carcinoma (Molinaro et al. 2017). On the other hand, there is a gap of knowledge on the features of primary squamous cell carcinoma of thyroid. This review aims to address this gap of knowledge by analysing the features of squamous cell carcinoma of thyroid and their relationships with other tumours of the thyroid gland.

\section{Method}

Primary squamous cell carcinoma of thyroid gland is extremely rare. It is not surprising that different authors give different values of the total number of cases reported in the literature because of the variation in criteria adopted for analysis. In population-based studies, since there are lack of detail of the individual patients, the number of cases appear to be over-estimated ( $\mathrm{Au}$ et al. 2017, Yang et al. 2019, Limberg et al. 2020). The largest of these studies was from the American College of Surgeons National Cancer Database in which 314 cases of primary squamous cell carcinoma of thyroid gland were reported between 2004 and 2015 (Limberg et al. 2020).

The current review is based on in-depth analysis of the cases reported in the English literature. All the thyroid carcinoma having features of squamous differentiation and those been reported as squamous cell carcinoma of thyroid in PubMed database were analysed. Cases without adequate individual data were excluded. In addition, the authorship and institutions were checked to exclude cases that were reported more than once in the literature.

Overall, 253 cases have been termed squamous cell carcinoma of thyroid gland with data on the clinical pathological features of individual patient available for analysis. The data were entered in a database for statistical analysis by the Statistical Package for the Social Sciences (SPSS) version 25 (IBM). Of these, 18 had no details of thyroid cancer histology, for example, cases with only fine-needle aspiration or core biopsy results without information on the histology of surgical specimens and thus by WHO definition, and could not be termed as 'squamous cell carcinoma'. Of the remaining 235 cases, 118 showed co-exiting carcinomas such as papillary thyroid carcinoma, follicular thyroid carcinoma or anaplastic thyroid carcinoma.

Strict adherence to the WHO definition of primary squamous carcinoma of thyroid was adopted, which is that the cancer must be $100 \%$ squamous cell carcinoma without the presence of other cancer component. Thus, only 117 cases fit the pathological criteria of the current
WHO definition of primary squamous cell carcinoma of thyroid gland and could be entered into in-depth review of the features (Roeder 1921, Goldman 1964, Prakash et al. 1968, Huang \& Assor 1971, Bahuleyan \& Ramachandran 1972, Kukreti et al. 1972, Kampsen et al. 1977, Lee et al. 1980, Shimaoka \& Tsukada 1980, Saito et al. 1981, Budd et al. 1982, Segal et al. 1984, Kapoor et al. 1985, Huang \& Lin 1986, Englender \& harell 1987, Riddle \& Dincsoy 1987, Misonou et al. 1988, Sarda et al. 1988, Simpson \& Carruthers 1988, Harada et al. 1989, Korovin et al. 1989, Tsuchiya et al. 1990, Theander et al. 1993, Chaudhary et al. 1994, Carter \& Milroy 1996, Wan Muhaizan et al. 1998, Cook et al. 1999, Kumar et al. 1999, Jones et al. 2000, Kleer et al. 2000, Agrawal et al. 2001, Lam et al. 2001a, Sahoo et al. 2002, Zhou 2002, Zimmer et al. 2003, Sanchez-Sosa et al. 2006, Ab Hadi et al. 2007, Chintamani et al. 2007, Fassan et al. 2007, Makay et al. 2008, Müssig et al. 2008, Long et al. 2009, Ashraf et al. 2010, Bonetti et al. 2010, Chen et al. 2010, Yucel et al. 2010, Batchelor 2011, Chen et al. 2012, Ko et al. 2012, Rosa \& Toronczyk 2012, Shrestha et al. 2013, Sapalidis et al. 2014, Bolfi et al. 2014, Jang et al. 2014, Chavan et al. 2015, Chu et al. 2016, Lichiardopol et al. 2016, Struller et al. 2017, Wygoda et al. 2017, Ibrahim et al. 2018, Koyama et al. 2018, Yasumatsu et al. 2018, De Cesare et al. 2019, Kao et al. 2019, Raggio et al. 2019).

\section{Epidemiology}

Lam and colleagues revealed the histology of 895 primary thyroid malignant tumours in a single intuition over a 30-year period (Lam et al. 2005). They noted that primary squamous cell carcinoma comprised $0.5 \%$ and anaplastic thyroid carcinoma accounted for $4.2 \%$ of the thyroid cancers. In a population-based study, Limberg and colleagues showed that primary squamous cell carcinoma and anaplastic thyroid carcinoma accounted for $0.3 \%$ and $2.6 \%$ of primary thyroid malignancies, respectively (Limberg et al. 2020). In another population-based study, Yang and colleagues reported that primary squamous cell carcinoma of thyroid accounted for $0.12 \%$ of thyroid cancers from 1873 to 2015 in USA (Yang et al. 2019). Overall, primary squamous cell carcinoma accounted for no more than $0.5 \%$ of primary thyroid cancer. Anaplastic thyroid carcinoma is more than eight times commoner than primary squamous cell carcinoma. Of interest, Yang and colleagues also reported the annual incidence of primary squamous cell carcinoma of thyroid decreased from $0.4 \%$ in 1973 to $0.1 \%$ in 2015 . The drop in the incidence of the thyroid carcinoma may be related to the (c) 2020 Society for Endocrinology Published by Bioscientifica Ltd. Printed in Great Britain 
earlier diagnosis and treatment of related thyroid disease as well as rise in incidence of papillary thyroid carcinoma.

Geographically, the reported cases in Asia comprised $48 \%(n=56)$ of the cases with most of the cases reported in Japanese patients. The other patients were reported approximately equally in America $(27 \% ; n=32)$ (occur mainly in USA) and Europe $(25 \% ; n=29)$ (mainly in United Kingdom).

From the accumulated data in the literature, the 117 primary squamous cell carcinomas occur in 83 women and 34 men. The female to male ratio is 2.4 to 1 , with women accounting for $71 \%$ of the patients with primary squamous cell carcinoma. The female predominance of the cancer is lower than those in patients with conventional papillary thyroid carcinoma with the ratio of female to male between 3 and 4 to 1 (Lam et al. 2005). In a populationbased study, based on the Surveillance, Epidemiology, and End Results Program (SEER) 18-registery database in USA between 1973 and 2015, Yang and colleague noted that the female to male ratio of primary squamous cell carcinoma of thyroid is 1.4 to 1 (Yang et al. 2019).

For anaplastic carcinoma, in a large series of 188 patients from Slovenia, the female to male ratio is 2.2 to 1 (Besic et al. 2005). Limberg and colleagues analysed the American College of Surgeons National Cancer Database and reported similar gender proportion between anaplastic thyroid carcinoma and primary thyroid squamous cell carcinoma (Limberg et al. 2020). Like the findings from the study of Yang and colleagues, lower female to male ratio for both carcinomas were noted and lower when compared to the papillary thyroid carcinoma (Yang et al. 2019).

From the pooled data of the 117 primary squamous cell carcinomas of thyroid, the age of patients with primary squamous cell carcinoma ranged from 13 to 89 . The carcinoma was most often seen in the seventh decade (Fig. 1). The mean age at presentation of these patients was 61 and the median age at presentation was 64 . The mean age is lower than those patients with thyroid carcinoma having anaplastic carcinoma and squamous carcinoma component (mean age $=66, P=0.002$ ). There is no gender difference in age distribution for the primary squamous cell carcinoma of the thyroid gland. Seventy-six per cent of the carcinomas occurred in the patients between the sixth and eight decades and more than $60 \%$ of the reported cases presented at age 60 or above. The results were like the population-based studies in USA with a mean age at presentation of 68 (Au et al. 2017, Limberg et al. 2020). Thus, primary squamous cell carcinoma occurs in a much older age group than conventional papillary thyroid carcinoma with mean age of presentation at fifth decade (Lam et al. 2005). In addition, patients with primary squamous cell carcinoma were found in patients slightly younger than those with anaplastic thyroid carcinoma (mean age at presentation often at eight decade with median age of 72) (Lo et al. 1999, Lam et al. 2000, Limberg et al. 2020).

\section{Clinical features}

Primary squamous cell carcinoma of thyroid resembles anaplastic thyroid carcinoma in clinical presentation. Patients with the carcinoma typically present with rapidly increasing neck mass invading the adjacent structures and with accompanying cervical lymphadenopathy. Obstructive symptoms related to the mass effect of the cancer such as dysphagia, dyspnoea, hoarseness and

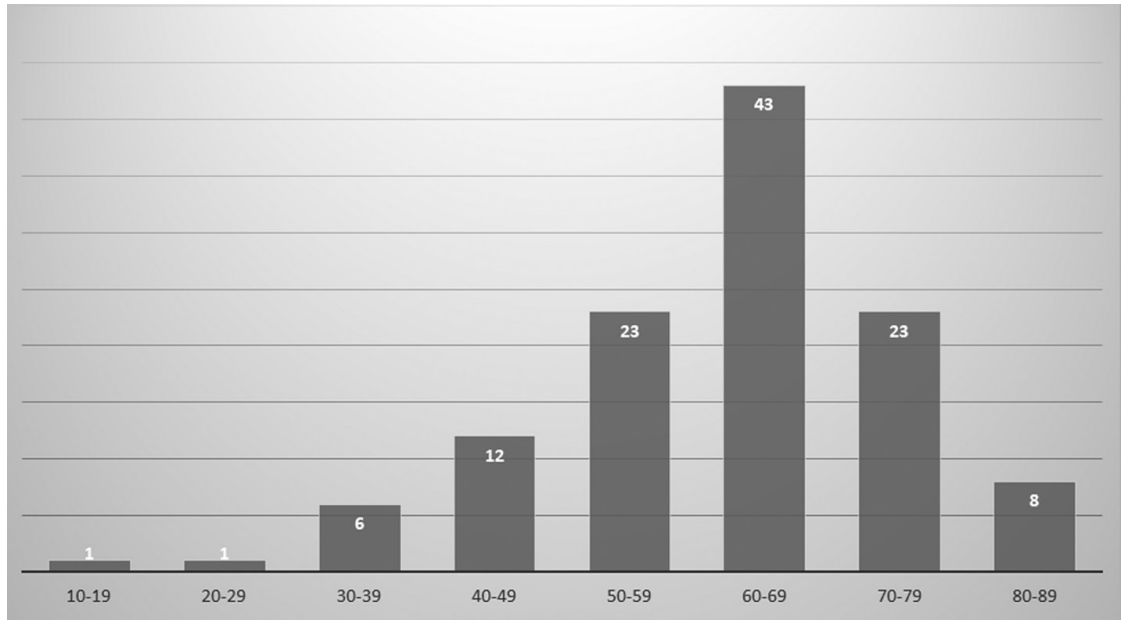

Figure 1

Bar chart showing the distribution of cases of primary squamous cell carcinoma of thyroid gland in different age groups, separated into decades of life. (c) 2020 Society for Endocrinology Published by Bioscientifica Ltd. Printed in Great Britain 
neck pain may be present. Also, patients may have a longstanding history of goitre or thyroid diseases. In the literature, 16 of the 117 patients with primary squamous cell carcinoma of thyroid had documented Hashimoto's thyroiditis/lymphocytic thyroiditis. In addition, Yucel and colleagues reported a case of primary squamous cell carcinoma of thyroid 25 years after radioactive iodine treatment of hyperthyroidism (Yucel et al. 2010).

Paraneoplastic manifestations have been reported in anaplastic thyroid carcinoma. The manifestations comprise ectopic secretion of human chorionic gonadotrophin $(\mathrm{Gu}$ et al. 2018), fibroblastic growth factor 23 (giving rise to osteomalacia) (Abate et al. 2016), granulocyte colonystimulating factor (give rise to leucocytosis) (Kang et al. 2013), parathyroid hormone-related protein (give rise to hypercalcemia) (Iwai et al. 2004) as well as hypertrophic osteoarthropathy likely to be the effect of secretion of platelet derived growth factor or vascular endothelial growth factor (Vico et al. 1992). Similar to anaplastic thyroid carcinoma, paraneoplastic manifestations could occur in patients with primary squamous cell carcinoma of thyroid. Two cases of primary squamous cell carcinoma had rare combination of paraneoplastic features of hypercalcemia and leucocytosis (Saito et al. 1981, Riddle \& Dincsoy 1987). The features were due to the parathyroid hormone-related protein and granulocyte colony-stimulating factor. Combination of hypercalcemia and leucocytosis in squamous cell carcinoma is rare and have been reported in anaplastic thyroid carcinoma (Yazawa et al. 1995) as well as squamous cell carcinomas of lung, penis and tongue (Burzyantseva et al. 2009, Doraiswamy et al. 2010, Kaneko et al. 2016). Thus, hypercalcemia-leucocytosis paraneoplastic syndrome is a feature of squamous cell carcinoma and could be a clinical presentation of primary squamous cell carcinoma of thyroid. Overall, paraneoplastic syndromes occur rarely in biological aggressive thyroid carcinomas with follicular cell differentiation, namely anaplastic thyroid carcinoma and primary squamous cell carcinoma. The spectrum of paraneoplastic syndromes reported is less in primary thyroid squamous cell carcinoma.

\section{Pre-operative investigation}

Ultrasonic investigation with fine-needle aspiration biopsy is the first line investigation for patients with suspected malignant lesion in the thyroid gland. Fineneedle aspiration was mentioned in 42 of the 117 patients with primary squamous cell carcinoma. There were eight cases diagnosed as negative for malignancy (including one diagnosed as an abscess) and one case was diagnosed as Hürthle cell neoplasm (Sahoo et al. 2002). Thus, fineneedle aspiration biopsy was sensitive to detect the malignant nature of the disease in only $79 \%$ of cases. In addition, diagnosis of squamous cell carcinoma was made in less than one-third of cases $(n=11 ; 26 \%)$. In this situation, they were most often diagnosed as either malignant tumour or carcinoma $(n=14,33 \%)$. The rest of the cases were diagnosed as anaplastic thyroid carcinoma or papillary thyroid carcinoma. It is worth noting that atypical squamous cell in the fine-needle aspiration biopsy of thyroid nodule is not diagnostic of squamous cell carcinoma. The most common diagnosis is squamous metaplasia in the setting of Hashimoto's thyroiditis and degenerative changes. Gage and colleagues have reviewed 15 cases of fine-needle aspirates with abundant squamous cells and only one case is confirmed as squamous cell carcinoma (Gage et al. 2016).

After the diagnosis of malignant lesion in thyroid, the extent of the disease should be assessed by further radiological means such as CT scan, MRI scan and up18F-FDG PET/CT (Caballero Gullón et al. 2017). Endoscopic examination of the upper aerodigestive tract should be used to exclude lesion (s) in the upper aerodigestive tract.

\section{Macroscopic features}

From the pooled data of 117 cases in the literature, primary squamous cell carcinoma occurs roughly in equal frequencies in right and left side of the thyroid. The tumour involves one or extends to both lobes of the thyroid gland with occasional satellite nodules. Primary thyroid squamous cell carcinoma is typically larger than papillary thyroid carcinoma and involves extensively or the entire lobe of the thyroid. The mean diameter of papillary thyroid carcinoma, conventional variant, was small (26 mm) (Lam et al. 2005), whereas that of anaplastic thyroid carcinoma was large $(80 \mathrm{~mm})$ (Lam et al. 2000). It appears that squamous cell carcinoma of thyroid is slight smaller than anaplastic thyroid carcinoma. From the pooled data in the literature, the mean diameter of the squamous cell carcinoma of thyroid was $54 \mathrm{~mm}$ and the size of the carcinoma was not dependent on the location of the tumour. Similar findings were noted in populationbased studies with mean diameter of 53-68 mm noted, respectively, in two studies (Yang et al. 2019, Limberg et al. 2020). Like squamous cell carcinoma elsewhere, (c) 2020 Society for Endocrinology Published by Bioscientifica Ltd. Printed in Great Britain 


\section{Endocrine-Related} Cancer

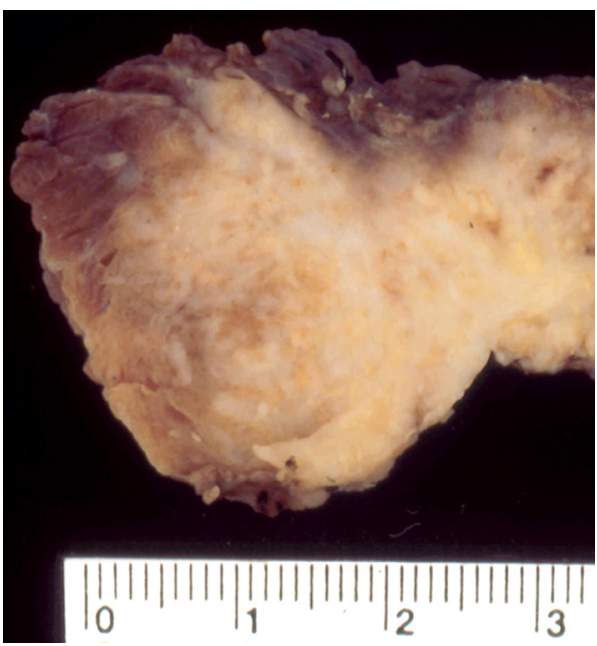

\section{Figure 2}

Macroscopic appearance of squamous cell carcinoma of thyroid showing extensive replacement of nearly the whole thyroid gland by firm whitish cancer tissue.

squamous cell carcinoma of thyroid often has a firm consistency and greyish-white colour with areas of necrosis and haemorrhages (Fig. 2).

\section{Microscopic features}

Primary squamous cell carcinoma of thyroid often shows extensive infiltration of the peri-thyroidal soft tissue with prominent vascular and peri-neural infiltration. From the data available, 93\% of the tumours involve outside the thyroid gland (T3 or T4). Squamous carcinomas were moderately differentiated in $51 \%$, poorly differentiated in $37 \%$ and well differentiated in $12 \%$. Thus, like most of the squamous cell carcinomas from the upper aerodigestive tract which infiltrate the thyroid, squamous cell carcinomas of thyroid gland were often moderately differentiated (Lam \& Yuen 1996). Nevertheless, grade 3 (poorly differentiated) carcinoma contributes more than one-third of the primary thyroid squamous cell carcinomas (Fig. 3). The portion of grade 3 carcinoma in primary squamous cell carcinoma of thyroid is higher than squamous cell carcinoma of upper aerodigestive tract such as in larynx (Lam \& Yuen 1996), which may give a hint for the origin of the squamous cell carcinoma in the thyroid gland on histological examination.

\section{Histological link with other carcinomas}

Squamous cell carcinoma component could be a component of a thyroid carcinoma. In the third edition

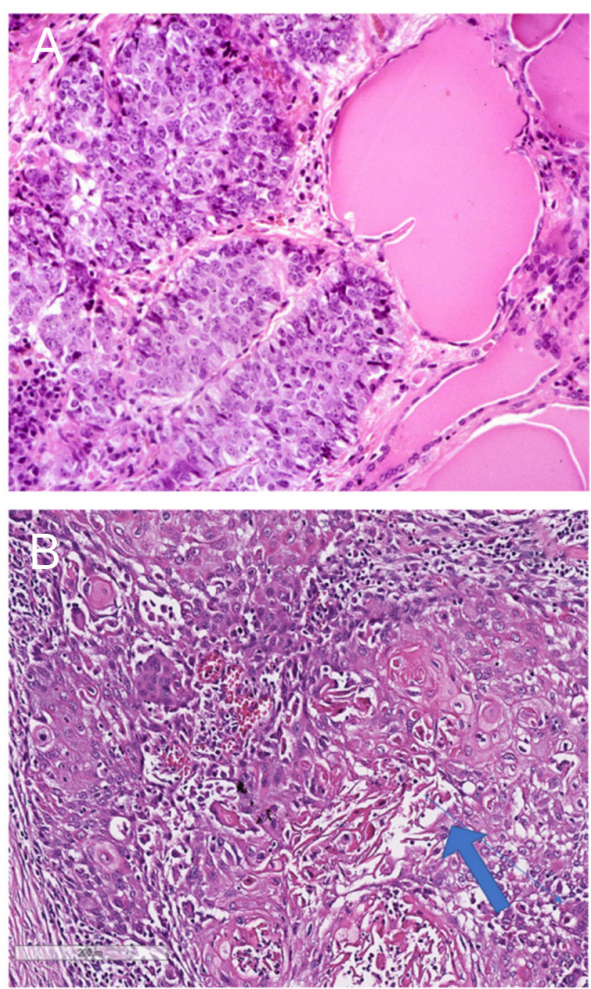

\section{Figure 3}

(A) Microscopic appearance of squamous cell carcinoma of thyroid showing a poorly differentiated (grade 3 ) squamous cell carcinoma with a few residual normal thyroid glands. (B) The other portion of the tumour showing more prominent squamous areas with keratin (arrow) (haematoxylin and eosin).

of WHO classification of tumours of endocrine organs (LiVolsi et al. 2004), papillary thyroid carcinoma with squamous cell carcinoma is a variant of papillary thyroid carcinoma. In the current WHO classification, primary squamous cell carcinoma of thyroid is defined as a carcinoma exclusively of squamous differentiation. Anaplastic carcinoma with squamous differentiation is termed 'anaplastic thyroid carcinoma'. Papillary thyroid carcinoma could have squamous differentiation. This group of carcinomas is noted to have more poor longterm outcomes (Beninato et al. 2018).

Of the 117 thyroid carcinomas with squamous differentiation collected in the English literature in this review, 95\% $(n=112)$ had papillary thyroid carcinoma and $5 \%$ had follicular thyroid carcinoma $(n=5)$. One case showed squamous differentiation as well as the presence of papillary thyroid carcinoma and follicular thyroid carcinoma. Half $(n=56)$ of these papillary thyroid carcinomas were tall cell variants, which had more aggressive biological behaviour (Lam 2017). In 49 of the papillary thyroid carcinomas having squamous carcinoma component, there were co-existing anaplastic thyroid 
carcinoma. By WHO definition, these cases were anaplastic carcinomas with squamous differentiation. Overall, the frequent occurrence of all these carcinomas is a strong evidence for the aetiological link between them. Hence, before diagnosing a primary squamous cell carcinoma of thyroid, it is important to look for the anaplastic thyroid carcinoma and well-differentiated thyroid carcinoma.

\section{Immunohistochemical features}

From the data of the primary cell carcinoma of thyroid collected in this review, only $4 \%(1 / 25)$ and $17 \%(3 / 18)$ of carcinomas tested are positive for thyroglobulin and TTF-1. Accordingly, primary squamous cell carcinoma of thyroid rarely stains for thyroglobulin or TTF-1 (thyroid transcription factor 1). In thyroid carcinomas other than well-differentiated thyroid carcinomas, PAX-8 (paired box gene 8 ) protein appears to be a more sensitive marker for confirming the thyroid origin of the carcinoma than TTF-1 or thyroglobulin (Fig. 4). In anaplastic thyroid carcinoma, multi-institution study showed that approximately half of the anaplastic thyroid carcinoma were positive for PAX-8 (Lai et al. 2020). Due to its rarity, the number of primary squamous cell carcinoma tested for PAX-8 was small. In the literature, only one case was negative for PAX-8 which was performed on autopsy tissue. Other than this, all the primary thyroid squamous cell carcinoma as well as squamous carcinoma component in association with other thyroid carcinomas showed positive to PAX-8 protein. In addition, Suzuki and colleagues showed that 91\% (10 of the 11) of thyroid tumours having squamous cell carcinoma component stained positive for PAX-8 (Suzuki et al. 2018).

p63 and p40 are sensitive markers for squamous differentiation, with p40 more specific than p63 in identifying squamous carcinoma (Bishop et al. 2012) (Fig. 5).

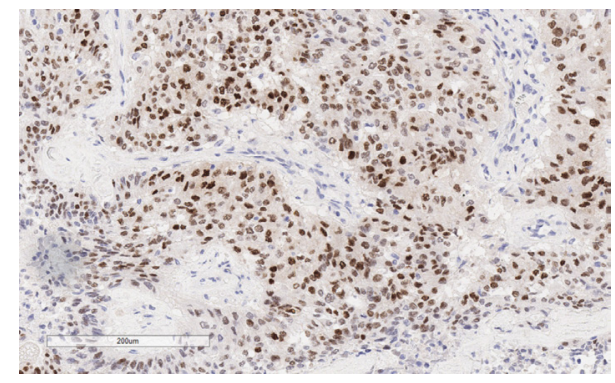

Figure 4

Squamous cell carcinoma of thyroid showing positive nuclear staining to PAX-8.

https://erc.bioscientifica.com https://doi.org/10.1530/ERC-20-0045
(C) 2020 Society for Endocrinology Published by Bioscientifica Ltd. Printed in Great Britain

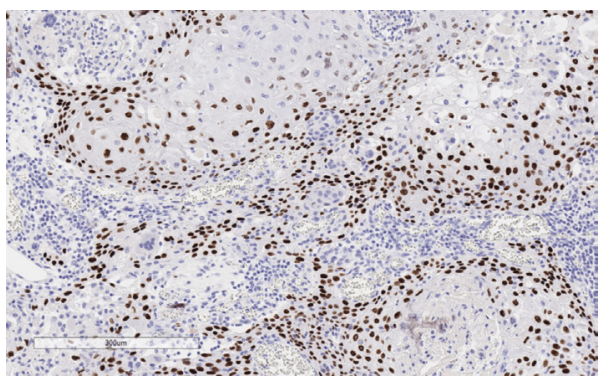

Figure 5

Squamous cell carcinoma of thyroid showing positive nuclear staining to p40.

All the ten primary thyroid squamous cell carcinomas tested in the literature were positive for p63. In addition, p40 was positive in two cases tested.

Cytokeratin profiles have been documented in different thyroid carcinomas (Lam et al. 2001b). The common pattern noted in thyroid carcinomas are positive for cytokeratins 7, 18 and 19 (simple epithelialtype/low molecular weight cytokeratins) but negative for cytokeratin 20 (also simple epithelial-type/low molecular weight cytokeratin). Like these carcinomas, primary thyroid squamous cell carcinomas noted in the literature showed positive to cytokeratin 19 (16/16), cytokeratin $7(13 / 14)$ and negative for cytokeratin $20(0 / 11)$.

Cytokeratin 5/6 and cytokeratin 10/13 are highmolecular-weight cytokeratins. Cytokeratin 5/6 is a marker of squamous cell carcinomas (Kaufmann et al. 2001, Kasem \& Lam 2020). All the primary thyroid squamous cell carcinomas tested in the literature showed positivity to cytokeratin 5/6 (14/14). On the other hand, cytokeratin $10 / 13$ was negative in the six cases tested by Lam et al. (2001a) and Bonetti et al. (2010). It is worth noting that cytokeratin 10/13 could be positive in anaplastic thyroid carcinoma (Lam et al. 2001b) as well as squamous cell carcinoma from upper aerodigestive tract squamous cell carcinoma, such as oesophageal squamous cell carcinoma (Lam et al. 2001a).

P53 overexpression is common in cancers with biological aggressive behaviour (Lam et al. 1999a, 2008). The expression is often absent in well-differentiated thyroid carcinoma (papillary thyroid carcinoma) and poorly differentiated thyroid carcinoma (Lam et al. 2000). On the other hand, Lam and colleagues reported p53 expression in $69 \%(20 / 29)$ of anaplastic thyroid carcinoma (Lam et al. 2000). Similarly, $75 \%(12 / 16)$ of primary thyroid squamous carcinomas collected in the literature showed p53 overexpression. Thus, like anaplastic thyroid carcinoma, primary thyroid squamous cell carcinoma showed high frequency of p53 overexpression (Fig. 6). 


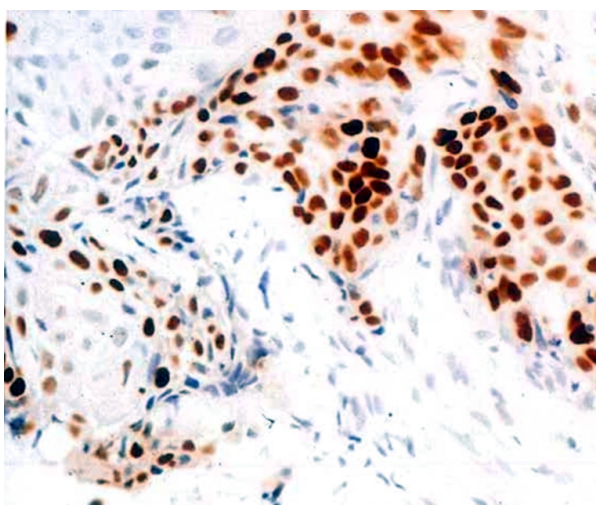

Figure 6

Squamous cell carcinoma of thyroid showing positive nuclear staining of p53.

\section{Differential diagnoses}

The most important clinical or pathological differential diagnosis of squamous cell carcinoma of thyroid is the differentiation from the direct infiltration of squamous cell carcinoma of the adjacent aerodigestive tract (oral cavity, tongue, proximal oesophagus, hypopharynx, larynx, nasopharynx and hypopharynx) (Lam \& Lo 1998, Vatsyayan et al. 2019). The most common site is from larynx (Nakhjavani et al. 1999). In a large series, infiltration of thyroid gland by laryngeal squamous cell carcinoma was present in $16 \%$ of cases (Lam \& Yuen 1996). Direct infiltration of the thyroid by adjacent carcinoma is usually discovered at the time of surgery on histological examination. In addition to direct infiltration, squamous cell carcinoma could metastasize to thyroid from organs such as lung or rarely from cervix (Lam \& Lo 1998, Varlı et al. 2019).

In contrast to the prominent clinical signs and symptoms of primary thyroid squamous cell carcinoma, the diagnosis of metastatic squamous carcinoma to thyroid gland is more often incidental (Lam \& Lo 1998, Vatsyayan et al. 2019). Most metastases to thyroid gland presented either simultaneously (61\%) or after detection (42\%) of the primaries. Apart from clinical and radiological features, immunohistochemical studies are helpful in the differential diagnosis. Suzuki and colleagues demonstrated that PAX-8 is positive in squamous carcinomas of thyroid gland, whereas squamous cell carcinomas from cervix, oesophagus and lung were negative for PAX-8 (Suzuki et al. 2018). It is worth noting that PAX-8 is positive for renal epithelial tumours such as renal cell carcinoma and neuroendocrine tumours (Long et al. 2010, El-Maqsoud et al. 2016). Thus, if malignant cells were noted on fineneedle aspiration, use of PAX-8 could not differentiate metastatic renal cell carcinoma (a common metastatic carcinoma to thyroid) from primary thyroid carcinomas. On the other hand, CD10 antibody may be helpful, as renal cell carcinoma is positive and squamous cell carcinoma of thyroid is negative.

Anaplastic carcinoma of thyroid comprises of sarcomatoid, giant cell and epithelial forms (Lam et al. 2000). The epithelial form manifests as squamoid or squamous cohesive tumour nests and is the predominate pattern in $18 \%$ of anaplastic thyroid carcinoma (Lam et al. 2000). Difference from primary squamous cell carcinoma, the epithelial form of anaplastic thyroid carcinoma, often has other histological patterns rather than pure squamous carcinoma. The clinical and histological similarities between epithelial form of anaplastic thyroid carcinoma and primary squamous cell carcinoma of thyroid highlight the proposed aetiological link between these two entities.

Intrathyroid thymic carcinoma, carcinoma showing thymus-like element (CASTLE), is a malignant epithelial tumour of the thyroid gland with thymic epithelial differentiation. The carcinoma occurred most often in Asian populations (Kakudo et al. 2013). The histological features of intrathyroid thymic carcinoma is identical to that of thymic carcinoma in the mediastinum. It is a squamous cell carcinoma with lymphocyte-rich stroma. Occasional single-cell keratinization or stratification of keratinizing tumour cells could be found, which could be misinterpreted as squamous cell carcinoma. However, intrathyroid thymic carcinoma is positive for CD5. All the primary thyroid squamous cell carcinomas $(n=11)$ tested in the literature were negative for CD5. In contrast to patients with thyroid squamous cell carcinoma, patients with intrathyroid thymic carcinoma had excellent outcomes after curative resection. In addition, intrathyroid thymic carcinoma often have low Ki-67 index of 10 to $30 \%$, whereas primary squamous carcinoma often has high Ki-67 index (Fig. 7). In this review of literature on

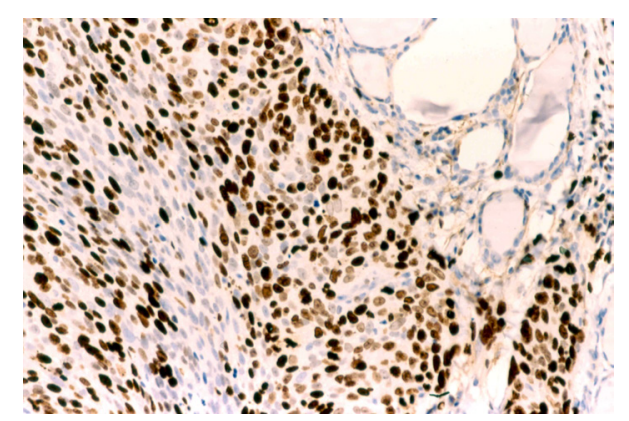

\section{Figure 7}

Squamous cell carcinoma of thyroid showing high proliferative index with high percentage of Ki-67 stained nuclei in the cancer cells. 
primary squamous cell carcinoma of thyroid, approaching $80 \%(11 / 14 ; 79 \%)$ had a Ki-67 index of $30 \%$ or above.

Mucoepidermoid carcinoma and sclerosing mucoepidermoid carcinoma with eosinophilia are rare carcinomas of thyroid gland with both epidermoid and mucin differentiation (Shah et al. 2017, Le et al. 2019). The epidermoid component, if predominant, could mimic primary squamous cell carcinoma of thyroid. In contrast, in squamous cell carcinoma of thyroid, there is no mucin component. Sclerosing mucoepidermoid carcinoma with eosinophilia also displays eosinophilic infiltration and is consistently associated with Hashimoto' thyroiditis. Different from primary thyroid squamous cell carcinoma, both mucoepidermoid carcinoma and sclerosing mucoepidermoid carcinoma carcinomas are low grade malignant tumours, though distant metastases could occur in both carcinomas.

Papillary thyroid carcinoma could have focal or extensive squamous differentiation in 20 to $40 \%$ of cases (Rosai et al. 2017). In addition, there are two variants of papillary thyroid carcinoma that have characteristic squamous structures, namely diffuse sclerosing variant and cribriform-morular variant. Diffuse sclerosing variant of papillary thyroid carcinoma (Lam \& Lo 2006, Pillai et al. 2015) occurs often in young woman with mean age at presentation at 30 . Higher prevalence of the carcinoma was noted in paediatric patients and in patients affected by irradiation. The carcinoma extensively infiltrates the thyroid and has extensive squamous differentiation and fibrosis which could mimic primary squamous cell carcinoma of thyroid. Nevertheless, numerous psammoma bodies in the carcinoma could differentiate the carcinoma from primary squamous cell carcinoma of thyroid. Cribriform-morular variant of papillary thyroid carcinoma occurred almost exclusively in young women (mean age =24) (Lam \& Saremi 2017, Lam \& Fridman 2018). These morules together with the absence of psammoma body in this variant of papillary thyroid carcinoma could superficially mimic primary squamous cell carcinoma of thyroid. Nevertheless, the immunohistochemical features of morules are different from squamous differentiation (being positive to bcl-2 and negative or focally positive to high-molecular-weight cytokeratin: cytokeratin 19). In addition to the morules, there is cribriform pattern of tumour cells. Furthermore, nuclear and cytoplasmic staining for beta catenin is a characteristic of cribriformmorular variant of papillary thyroid carcinoma. In contrast with primary squamous cell carcinoma of thyroid, patients with cribriform-morular variant of papillary thyroid carcinoma have relatively indolent behaviour.

\section{Molecular biology}

Due to the rarity of the disease, there are limited data on molecular biology studies of primary squamous cell carcinoma of thyroid (Table 1). The only gene that has been studied in thyroid carcinomas having squamous carcinoma component was BRAF (v-Raf murine sarcoma viral oncogene homolog B). BRAF V600E mutation is present in many human cancers (Pakneshan et al. 2013, $\mathrm{Ng}$ et al. 2019). It is the main player in papillary thyroid

Table 1 Molecular biology studies on thyroid carcinoma with squamous cell carcinoma component.

\begin{tabular}{|c|c|c|c|c|c|}
\hline \multirow[b]{2}{*}{ Year/first author } & \multicolumn{4}{|c|}{ Mutations } & \multirow[b]{2}{*}{ Remarks } \\
\hline & $B R A F$ & KRAS & P53 & EGFR & \\
\hline \multicolumn{6}{|c|}{ Primary squamous cell carcinoma of thyroid } \\
\hline 2000/Kleer & - & - & - & - & No LOH P53 \\
\hline 2010/Bonetti & ND & ND & ND & ND & Low EGFR polysomy, no amplification \\
\hline 2010/Bonetti & ND & ND & ND & ND & High EGFR polysomy, no amplification \\
\hline 2012/Ko & + & - & - & ND & BRAF V600E (exon 15) and G468A (exon 11) \\
\hline 2016/Chu & - & - & - & - & $\begin{array}{l}\text { whole genome sequencing with multiple mutations, no } \\
\text { CDKN2A or NOTCH }\end{array}$ \\
\hline \multicolumn{6}{|c|}{ Papillary thyroid carcinoma with squamous carcinoma component } \\
\hline 2000/Kleer & ND & ND & - & ND & NO LOH of P53 \\
\hline 2000/Kleer & ND & ND & + & ND & $\mathrm{LOH}$ of $\mathrm{P} 53$ \\
\hline 2010/Rausch & + & ND & - & ND & $\begin{array}{l}\text { BRAF mutation in both papillary squamous components; } \\
\text { negative for microsatellite instability }\end{array}$ \\
\hline 2013/Lee & + & ND & ND & ND & $B R A F$ mutation in both papillary squamous components \\
\hline 2016/Acosta & + & - & ND & - & $\begin{array}{l}\text { negative for } A L K \text { mutation, } B R A F \text { mutation in both } \\
\text { papillary and squamous components }\end{array}$ \\
\hline 2017/Rupani & + & ND & ND & ND & $B R A F$ mutation in both papillary squamous components \\
\hline 2018/Dennis & + & ND & ND & ND & BRAF mutated protein in the squamous component. \\
\hline \multicolumn{6}{|c|}{ LOH: loss of heterozygosity; ND, not done. } \\
\hline $\begin{array}{l}\text { https://erc.bioscientifica.com } \\
\text { https://doi.org/10.1530/ERC-20-0045 }\end{array}$ & $\begin{array}{l}\text { (C) } 202 \\
\text { Put }\end{array}$ & $\begin{array}{l}\text { ety for } \\
\text { by Bio } \\
\text { inted in }\end{array}$ & $\begin{array}{l}\text { inology } \\
\text { fica Ltd. } \\
\text { Britain }\end{array}$ & & \\
\hline
\end{tabular}


carcinoma and is associated with clinical pathological features and survival of patients with the cancer. The Cancer Genomic Atlas (TCGA) documents that the genomics of papillary thyroid carcinomas are mainly by mutually exclusive driver mutations, either carrying the $B R A F$ V600E-like signatures or RAS (rat sarcoma viral oncogene homolog)-like gene signatures (including non-BRAF V600E $B R A F$ mutations) (Lam 2017). In primary squamous cell carcinoma of thyroid, only one case had mutations in $B R A F$ detected by Ko and colleagues (Ko et al. 2012). The mutations were in BRAF V600E (exon 15) as well as G468A (exon 11). In addition, there were four cases of papillary thyroid carcinoma with co-existing squamous carcinoma component having BRAF V600E mutation (Lee et al. 2013, Acosta \& Pins 2016, Rupani et al. 2017, Rausch et al. 2010) and one case with BRAF mutated protein detected (Dennis et al. 2018) in both the papillary and squamous carcinoma component of the carcinomas. The results suggest a strong link between papillary thyroid carcinoma and thyroid squamous cell carcinoma.

Anaplastic thyroid carcinoma is characterized by accumulation of several oncogenic alterations (Molinaro et al. 2017). It is one of the human cancers with the highest mutation loads. Genomic studies have showed that mutations in BRAF, TERT (telomerase reverse transcriptase) promotor, $p 53$ and EIF1AX (eukaryotic translation initiation factor $1 \mathrm{~A}, \mathrm{X}$-linked) are common in the carcinoma (Molinaro et al. 2017). In the literature, only one short report of primary squamous cell carcinoma was studied by whole genome sequencing by $\mathrm{Chu}$ and colleagues (Chu et al. 2016). The case showed different genetic profiles from anaplastic thyroid carcinoma. It showed no BRAF mutation. More genomic studies are needed to confirm the difference between primary squamous cell carcinoma of thyroid and anaplastic thyroid carcinoma.

The genomic profile in primary thyroid squamous cell carcinoma presented by $\mathrm{Chu}$ and colleagues showed absence of driver mutations commonly detected in squamous cell carcinoma such as p53, CDKN2A/p16 (cyclin-dependent kinase inhibitor 2A) and NORCH1 (Chu et al. 2016). There was no K-RAS mutation mentioned. $K-R A S$ mutation was not found in the primary thyroid squamous cell carcinoma presented by Ko et al. (2012) as well as in a case of papillary thyroid carcinoma with squamous carcinoma component reported by Acosta \& Pins (2016).

In primary squamous cell carcinoma of thyroid gland, no $p 53$ mutation was found by Kleer et al. (2000) and Ko et al. (2012). In addition, p53 genetic changes have been studied in three cases of papillary thyroid carcinoma with co-existing squamous carcinoma component (Kleer et al. 2000, Rausch et al. 2010). Only one of the three cases showed loss of heterozygosity (LOH) to p53 with overexpression of p53 protein (Kleer et al. 2000). The low prevalence of $p 53$ mutation contrasts with the high prevalence of p53 protein overexpression in primary squamous cell carcinoma of thyroid (see previous section). It is likely that mechanisms other than p53 mutation contributes to the overexpression of the protein.

EGF receptor (EGFR) alterations are common in human cancers (Tomas et al. 2014). EGFR mutations or amplifications were not identified in two primary squamous cell carcinomas (Bonetti et al. 2010, Chu et al. 2016) or in a papillary thyroid carcinoma with co-existing squamous carcinoma component (Acosta \& Pins 2016). Nevertheless, Bonetti and colleagues have detected overexpression of EGFR protein and EGFR polysomy in two patients with primary squamous cell carcinoma of thyroid (Bonetti et al. 2010). It is unlikely that EGFR plays a major role in the cancer.

Overall, due to the limitation of molecular studies in primary squamous cell carcinoma, there is no molecular evidence to draw conclusions on the molecular profiles of the carcinoma. There should be genomic studies on more primary squamous cell carcinoma and to compare the findings with those of anaplastic thyroid carcinoma as well the squamous cell carcinoma component of thyroid carcinomas.

\section{Metastases}

From the data in the literature, involvement of neck lymph node was noted in 59\% (60 of 102) of the patients with primary squamous cell carcinoma of the thyroid gland. For reference, lymph node metastases were approximately noted in 30\% of papillary thyroid carcinoma at the time of surgery (Lam et al. 2005). In anaplastic thyroid carcinoma, cervical lymphadenopathy was present in $64 \%$ (7 of 11) of cases in a single institution study in 2018 (Deeken-Draisey et al. 2018). Also, $56 \%$ of the 219 patients with anaplastic thyroid carcinoma noted in Danish databases have lymph node metastases (Hvilsom et al. 2018). Thus, primary thyroid squamous cell carcinoma had higher frequency of lymph node metastases than papillary thyroid carcinoma and similar frequency to anaplastic thyroid carcinoma.

Distant metastases were uncommon in papillary thyroid carcinoma. In biological aggressive variant, diffuse sclerosing variant, $5 \%$ of cases revealed lymph node 
metastases (Pillai et al. 2015). In the literature, distant metastases were documented in 26\% (27 of 106) of patients with primary squamous cell carcinoma of the thyroid gland. Most of the metastatic squamous carcinoma occurred in the lungs $(n=24)$. The other common site of metastases were bones $(n=7)$. Other than these, metastatic squamous cell carcinoma of thyroid had been detected in brain, liver, heart, kidney and diaphragm. The pattern of metastases noted concurred with those obtained in a populationbased study by Limberg and colleagues (Limberg et al. 2020). Compared to anaplastic thyroid carcinoma in which distant metastases were present in 50\% of patients on presentation (Lo et al. 1999), the prevalence of distant metastasis was lower in primary thyroid squamous cell carcinoma. The lower prevalence of distant metastases in primary squamous cell carcinoma could be related to its local aggressive behaviour, causing death of the patients before the occurrence of distant metastases.

\section{Prognosis}

The prognosis of patients with primary squamous cell carcinoma is dismal. In the 117 patients with squamous cell carcinomas of thyroid noted in the literature, 109 had follow-up data available. Of these, 88 patients died of the disease. The median survival of the patients was 8 months and a 2-year survival rate of $14 \%$. The results concurred with those from a population-based study of $\mathrm{Au}$ and colleagues on 199 primary thyroid squamous cell carcinomas which reported a median survival of 9.1 months (Au et al. 2017). Lo and colleagues, in a large series of patients with anaplastic thyroid carcinoma, found that the patients had median survival of 1.3 months and a 2 -year survival rate of $4 \%$ (Lo et al. 1999). In populationbased studies, the median survival of patients with anaplastic thyroid carcinoma reported was from 3 to 6 months (30717908). Thus, the prognosis of the patients with primary thyroid squamous cell carcinoma is better than those with anaplastic thyroid carcinoma.

Age at diagnosis, tumour grade, tumour size and presence of distant metastases are independent predictors for disease-specific survival of patients with primary thyroid squamous cell carcinoma in population-based studies from USA (Au et al. 2017, Yang et al. 2019, Limberg et al. 2020). From the pooled data in the literature from the primary thyroid squamous cell carcinoma, patients with distant metastases or lymph node metastases at presentation had poorer outcome than those without distant metastases $(P=0.022$ and

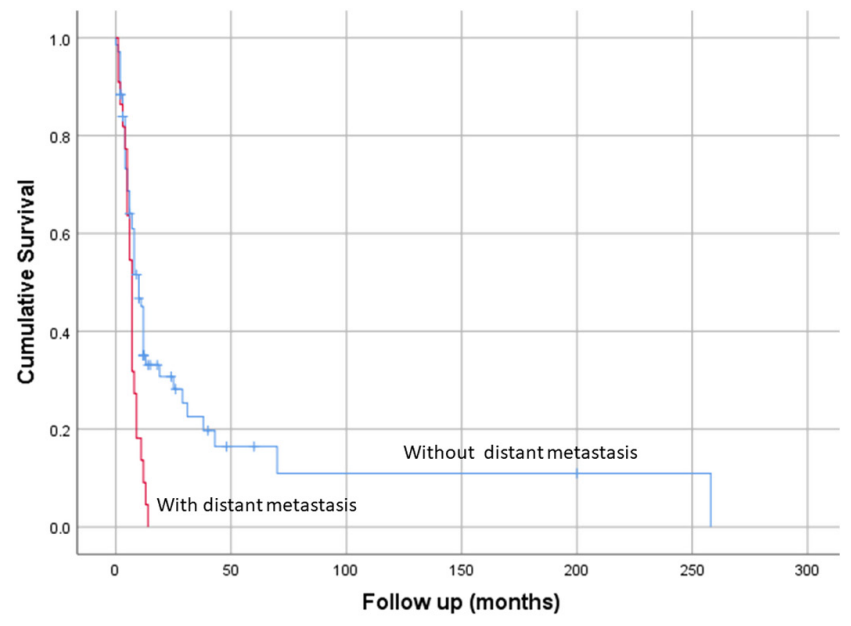

Figure 8

Survival analysis of primary squamous cell carcinoma of thyroid showing that patients without distant metastasis had better prognosis than those with distant metastasis.

$P=0.002$, respectively) (Fig. 8). On multivariant analysis, patients with primary thyroid squamous cell carcinoma having distant metastases had poorer survival rates $(P=0.01)$. Patients with younger age at diagnosis and smaller tumour size also had better prognosis but the difference did not reach statistical significance.

Lymphocytic infiltration including Hashimoto's thyroiditis are commonly associated with thyroid carcinomas and lymphomas (Lam et al. 1999b, Molnár et al. 2019). Asik and colleagues analysed the cases reported in the literature and noted that primary thyroid squamous cell carcinoma of thyroid with concurrent lymphocytic thyroiditis had lower pathological stages and frequency of distant metastases (Asik et al. 2015). In the current review, patients having primary thyroid squamous cell carcinoma with concurrent lymphocytic thyroiditis had slightly better survival rates than those patients without concurrent lymphocytic thyroiditis. However, the difference did not reach statistical significance $(P=0.09)$. Therefore, it appears that lymphocytic thyroiditis could limit the growth of the primary thyroid squamous cell carcinoma.

Squamous carcinoma component in papillary thyroid carcinoma is associated with demonstrated high rates of locoregional recurrence (60\%), pulmonary metastases (30\%) and mortality (10\%) (Beninato et al. 2018). In the current literature review, it is confirmed that squamous carcinoma component confers a poor prognosis in patients with well-differentiated thyroid carcinoma (predominately papillary thyroid carcinoma), with the median survival of the patients being 18 months. Nevertheless, there is a (c) 2020 Society for Endocrinology Published by Bioscientifica Ltd. Printed in Great Britain 


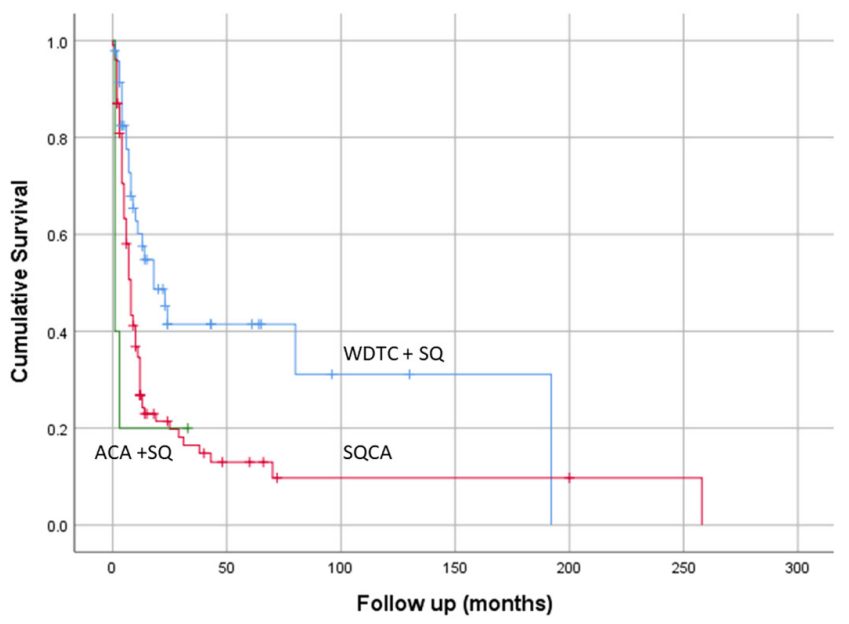

\section{Figure 9}

Survival analysis of different groups of thyroid carcinomas with squamous differentiation showing different survival rates. WDTC + SQ: welldifferentiated thyroid carcinoma with squamous carcinoma component; SQCA: primary thyroid squamous cell carcinoma ( $100 \%$ squamous carcinoma component); ACA + SQ: anaplastic carcinoma with squamous carcinoma component.

significant difference in the different groups of patients having thyroid carcinoma with squamous carcinoma component $(P=0.001)$ (Fig. 9). Patients with primary thyroid squamous cell carcinoma had poorer prognosis than patients with well-differentiated thyroid carcinoma having squamous carcinoma component (median survival, 8 months vs 18 months). In addition, patients having anaplastic thyroid carcinoma having squamous carcinoma component had poorer prognosis than those with pure squamous cell carcinoma of thyroid (median survival, 1 month vs 8 months). Overall, the results indicated that prognosis of squamous cell carcinoma is intermediate between anaplastic thyroid carcinoma (with squamous carcinoma component) and well-differentiated thyroid carcinoma with squamous carcinoma component.

\section{Clinical management}

Aggressive treatment approach with multidisciplinary team should be used whenever possible for patients with primary thyroid squamous cell carcinoma. From population-based studies, R1 resection (resection with microscopic residual tumour) is possible in $37.3 \%$ (Limberg et al. 2020) of the patients with primary thyroid squamous cell carcinoma. Curative resection for patients with squamous cell carcinoma of thyroid is more often possible than in patients with anaplastic thyroid carcinomas (Limberg et al. 2020).

Primary squamous cell carcinoma of thyroid gland is poorly responsive to radiotherapy and relatively resistant to chemotherapy. The carcinoma does not uptake iodine. Thus, there is no role for radioactive iodine ablation or thyroid suppression. The patients being treated with surgery alone appear to have the best survival rate $(\mathrm{Au}$ et al. 2017, Yang et al. 2019, Cho et al. 2014). In addition, patients with complete resection have better survival than those with incomplete resection (Cho et al. 2014).

Ultrasound examination of the primary lesion in the neck could detect hypoechoic irregular structure with local invasion suggestive of a malignant lesion before operation and help characterize neck node metastases. After operation, patients with primary squamous cell carcinoma of thyroid should be followed-up closely to identify residual carcinoma or recurrence of the carcinoma. Fluorodeoxyglucose (FDG) PET-CT is the most sensitive mean to detect distant metastases.

Target therapies using receptor kinase inhibitors that inhibit multiple angiogenic and oncogenic signalling pathways are the proposed approach for treatment of aggressive recurrent thyroid cancers including anaplastic thyroid carcinoma (Rahman et al. 2014, 2015). Lenvatinib is a multiple tyrosine kinase inhibitor used in the USA and European Union for this purpose. Yasumatsu and colleagues showed that the drug may show promise to potentially extend survival of patients with primary thyroid squamous cell carcinoma (Yasumatsu et al. 2018).

Adjuvant therapeutic approaches (chemotherapy and radiotherapy) have been used with limited benefit for patients with unresectable carcinoma or palliative resection having residual cancer. The new immunotherapy targeting the programmed cell death 1 (PD-1) receptor and its ligand PD-L1 is being used with many metastasizing carcinomas ( $\mathrm{Ng}$ et al. 2018). It stimulates the host response to cancer. In this context, expression of PD-L1 was noted in papillary thyroid carcinoma and anaplastic thyroid carcinoma (Ulisse et al. 2019). Immunotherapy has been approved by U.S. Food and Drug Administration (FDA) in many cancers including head and neck squamous cell carcinoma. Although no clinical trials have been done on this rare squamous cell carcinoma of thyroid, immunotherapy, alone or in combination with other therapy, could be considered for clinical trial in primary thyroid squamous cell carcinoma with residual or recurrent diseases. 
Table 2 Clinical pathological differences between anaplastic carcinoma and squamous cell carcinoma of thyroid gland.

\begin{tabular}{|c|c|c|}
\hline Features & $\begin{array}{l}\text { Anaplastic } \\
\text { carcinoma }\end{array}$ & $\begin{array}{l}\text { Squamous cell } \\
\text { carcinoma }\end{array}$ \\
\hline Prevalence & $\begin{array}{l}\sim 4.2 \% \text { of thyroid } \\
\text { cancers }\end{array}$ & $\begin{array}{l}\sim 0.5 \% \text { of } \\
\text { thyroid } \\
\text { cancers }\end{array}$ \\
\hline Median age & 72 & 64 \\
\hline Most common age group & Eighth decade & Seventh decade \\
\hline Female to male ratio & 2.2 to 1 & 2.4 to 1 \\
\hline $\begin{array}{l}\text { Mean diameter } \\
\text { Immunohistochemical } \\
\text { findings: }\end{array}$ & $80 \mathrm{~mm}$ & $54 \mathrm{~mm}$ \\
\hline PAX-8 & $54 \%$ & $80 \%$ a \\
\hline P53 expression & $69 \%$ & $75 \%$ \\
\hline CK10/13 & $0 \% a$ & $16 \%{ }^{a}$ \\
\hline Lymph node metastases & $64 \%$ & $59 \%$ \\
\hline Distant metastases & $50 \%$ & $26 \%$ \\
\hline Prognosis: & & \\
\hline 2-year survival & $4 \%$ & $14 \%$ \\
\hline Median survival & 1.3 months & 8 months \\
\hline
\end{tabular}

aBased on limited number of cases.

\section{Conclusion}

Primary squamous cell carcinoma is a very rare carcinoma of the thyroid. It is important to exclude clinically and pathologically other thyroid lesions with squamous carcinoma component before making the diagnosis. There is a suggested developmental relationship between squamous cell carcinoma and anaplastic thyroid carcinoma from well-differentiated thyroid carcinoma (predominately papillary thyroid carcinoma). Though anaplastic thyroid carcinoma and squamous cell carcinoma of thyroid share similar aggressive biological behaviour, there is difference between them in aspects like clinical pathological features and patients' prognosis (Table 2). There is need for more genomic studies to identify the pathway of development of anaplastic thyroid carcinoma and primary thyroid squamous cell carcinoma. There are marked differences in features between primary squamous cell carcinoma of thyroid and thyroid carcinomas with squamous carcinoma component, justifying the classification of squamous cell carcinoma of thyroid as a distinct entity. As curative resection is more often possible in squamous cell carcinoma than anaplastic thyroid carcinoma, it is important for early detection of primary thyroid squamous cell carcinoma for possible curative surgical resection. In addition, more genomic works to uncover the molecular pathogenesis and possible new target therapies including immunotherapy need to be done, as the cancer is relatively resistant to current chemotherapeutic modalities.

(c) 2020 Society for Endocrinology Published by Bioscientifica Ltd. Printed in Great Britain

\section{Declaration of interest}

The author declares that there is no conflict of interest that could be perceived as prejudicing the impartiality of this review.

\section{Funding}

This work did not receive any specific grant from any funding agency in the public, commercial or not-for-profit sector.

\section{References}

Ab Hadi I, Bliss RD, Lennard TW \& Welch AR 2007 Primary squamous cell carcinoma of the thyroid gland: a case report and role of radiotherapy. Surgeon 5 249-251. (https://doi.org/10.1016/s1479$666 x(07) 80010-2)$

Abate EG, Bernet V, Cortese C \& Garner HW 2016 Tumor induced osteomalacia secondary to anaplastic thyroid carcinoma: a case report and review of the literature. Bone Reports 5 81-85. (https://doi. org/10.1016/j.bonr.2015.11.004)

Acosta AM \& Pins MR 2016 Papillary thyroid carcinoma with extensive squamous dedifferentiation metastatic to the lung: BRAF mutational analysis as a useful tool to rule out tumor to tumor metastasis. Virchows Archiv 468 239-242. (https://doi.org/10.1007/s00428-0151875-8)

Agrawal R, Tandon V, Agrawal A, Agrawal G, Krishnani N \& Mishra SK 2001 Squamous cell carcinoma of thyroid gland. Journal of the Association of Physicians of India 49 279-280.

Ashraf MJ, Azarpira N, Khademi B \& Peiravi M 2010 Squamous cell carcinoma associated with tall cell variant of papillary carcinoma of the thyroid. Indian Journal of Pathology and Microbiology 53 548-550. (https://doi.org/10.4103/0377-4929.68286)

Asik M, Binnetoglu E, Sen H, Gunes F, Muratli A, Kankaya D, Uysal F, Sahin M \& Ukinc K 2015 Less aggressive disease in patients with primary squamous cell carcinomas of the thyroid gland and coexisting lymphocytic thyroiditis. Contemporary Oncology 19 458-461. (https://doi.org/10.5114/wo.2015.53372)

Au JK, Alonso J, Kuan EC, Arshi A \& St John MA 2017 Primary squamous cell carcinoma of the thyroid: a population-based analysis. Otolaryngology: Head and Neck Surgery 157 25-29. (https://doi. org/10.1177/0194599817698436)

Bahuleyan CK \& Ramachandran P 1972 Primary squamous cell carcinoma of thyroid. Indian Journal of Cancer 9 89-91.

Batchelor NK 2011 Primary squamous cell carcinoma of the thyroid: an unusual presentation. Journal of Bronchology and Interventional Pulmonology 18 168-170. (https://doi.org/10.1097/ LBR.0b013e3182170ff1)

Beninato T, Kluijfhout WP, Drake FT, Khanafshar E, Gosnell JE, Shen WT, Duh QY \& Suh I 2018 Squamous differentiation in papillary thyroid carcinoma: a rare feature of aggressive disease. Journal of Surgical Research 223 39-45. (https://doi.org/10.1016/j. jss.2017.10.023)

Besic N, Hocevar M, Zgajnar J, Pogacnik A, Grazio-Frkovic S \& Auersperg M 2005 Prognostic factors in anaplastic carcinoma of the thyroid-a multivariate survival analysis of 188 patients. Langenbeck's Archives of Surgery 390 203-208. (https://doi.org/10.1007/s00423-0040524-5)

Bishop JA, Teruya-Feldstein J, Westra WH, Pelosi G, Travis WD \& Rekhtman N 2012 p40 ( $\Delta$ Np63) is superior to p63 for the diagnosis of pulmonary squamous cell carcinoma. Modern Pathology 25 405-415. (https://doi.org/10.1038/modpathol.2011.173)

Bolfi F, Domingues MA, Sobrinho-Simões M, Soares P, Celestino R, Castilho EC, Carelli G, Paes NS \& Mazeto GM 2014 Primary 
squamous cell carcinoma of the thyroid diagnosed as anaplastic carcinoma: failure in fine-needle aspiration cytology? Case Reports in Pathology 2014 301780. (https://doi.org/10.1155/2014/301780)

Bonetti LR, Lupi M, Trani M, Trani N, Sartori G, Schirosi L, Bettelli S, Zanelli G, Maccio L \& Maiorana A 2010 EGFR polysomy in squamous cell carcinoma of the thyroid: report of two cases and review of the literature. Tumori 96 503-507. (https://doi. org/10.1177/030089161009600323)

Budd DC, Fink DL, Rashti MY \& Woo TH 1982 Squamous cell carcinoma of the thyroid. Journal of the Medical Society of New Jersey 79 838-840.

Burzyantseva O, Dharmasena S, Jayawardena S, Rupanagudi VA \& Krishnan P 2009 Hypercalcemia-leukocytosis syndrome in a patient with cavitating squamous cell carcinoma of the lung. Cases Journal 2 108. (https://doi.org/10.1186/1757-1626-2-108)

Caballero Gullón L, Carmona González E, Martínez Estévez A, Gómez Camarero MP, Corral JJ \& Borrego Dorado I 2017 Primary squamous cell carcinoma of the thyroid: initial assessment and follow-up using 18F-FDG PET/CT. Revista Espańola de Medicina Nuclear e Imagen Molecular 36 257-259. (https://doi.org/10.1016/j.remn.2017.01.001)

Carcangiu ML, Lam AKY \& Montone KT 2017 Squamous cell carcinoma. In WHO Classification of Tumours of Endocrine Organs, 4th ed., p. 107. Eds RV Lloyd, RY Osamura, G Koppel \& J Rosai. Lyon, France: IARC Press.

Carter N \& Milroy CM 1996 Thyroid carcinoma causing fatal laryngeal occlusion. Journal of Laryngology and Otology 110 1176-1178. (https://doi.org/10.1017/s0022215100136084)

Chaudhary RK, Barnes EL \& Myers EN 1994 Squamous cell carcinoma arising in Hashimoto's thyroiditis. Head and Neck 16 582-585. (https://doi.org/10.1002/hed.2880160615)

Chavan RN, Chikkala B, Biswas C, Biswas S \& Sarkar DK 2015 Primary squamous cell carcinoma of thyroid: a rare entity. Case Reports in Pathology 2015 838079. (https://doi.org/10.1155/2015/838079)

Chen CY, Tseng HS, Lee CH \& Chan WP 2010 Primary squamous cell carcinoma of the thyroid gland with eggshell calcification: sonographic and computed tomographic findings. Journal of Ultrasound in Medicine 29 1667-1670. (https://doi.org/10.7863/ jum.2010.29.11.1667)

Chen KH, Chou YH \& Cheng AL 2012 Primary squamous cell carcinoma of the thyroid with cardiac metastases and right ventricle outflow tract obstruction. Journal of Clinical Oncology 30 e260-e263. (https:// doi.org/10.1200/JCO.2011.39.9808)

Chintamani, PK, Kulshreshtha P, Singh J, Sugandhi N, Bansal A, Bhatnagar D \& Saxena S 2007 Is an aggressive approach justified in the management of an aggressive cancer - the squamous cell carcinoma of thyroid? International Seminars in Surgical Oncology 48. (https://doi.org/10.1186/1477-7800-4-8)

Cho JK, Woo SH, Park J, Kim MJ \& Jeong HS 2014 Primary squamous cell carcinomas in the thyroid gland: an individual participant data meta-analysis. Cancer Medicine 3 1396-1403. (https://doi. org/10.1002/cam4.287)

Chu TP, Chen WC, Wang TY \& Cheng SP 2016 Genetic alterations in primary squamous cell carcinoma of the thyroid. Pathology 48 523-525. (https://doi.org/10.1016/j.pathol.2016.04.008)

Cook AM, Vini L \& Harmer C 1999 Squamous cell carcinoma of the thyroid: outcome of treatment in 16 patients. European Journal of Surgical Oncology 25 606-609. (https://doi.org/10.1053/ejso.1999.0715)

De Cesare A, Di Cristofano C, Di Filippo AR, Salesi N, Spaziani M, Picchio M \& Spaziani E 2019 Total thyroidectomy associated to chemotherapy in primary squamous cell carcinoma of the thyroid. Clinica Terapeutica 170 e231-e234. (https://doi.org/10.7417/ CT.2019.2138)

Deeken-Draisey A, Yang GY, Gao J \& Alexiev BA 2018 Anaplastic thyroid carcinoma: an epidemiologic, histologic, immunohistochemical, and molecular single-institution study. Human Pathology 82 140-148. (https://doi.org/10.1016/j.humpath.2018.07.027)
Dennis K, O’Neil M \& Harrington A 2018 Not all neck mass fine-needle aspirations with squamous cells are squamous cell carcinoma; report of a case of recurrent thyroid carcinoma with papillary and squamous carcinoma components. CytoJournal 15 23. (https://doi. org/10.4103/cytojournal.cytojournal_19_17)

Doraiswamy VA, Biboa J, Obafemi A \& Goldschmid M 2010 Leukocytosis and hypercalcemia: a rare combination of paraneoplastic features in squamous cell penile cancer. Southern Medical Journal 103 474-476. (https://doi.org/10.1097/ SMJ.0b013e3181d7b802)

El-Maqsoud NM, Tawfiek ER, Abdelmeged A, Rahman MF \& Moustafa AA 2016 The diagnostic utility of the triple markers napsin A, TTF-1, and PAX8 in differentiating between primary and metastatic lung carcinomas. Tumour Biology 37 3123-3134. (https:// doi.org/10.1007/s13277-015-3964-3)

Englender M \& Harell M 1987 Primary squamous-cell carcinoma. Ear, Nose, and Throat Journal 66 422-424.

Fassan M, Pennelli G, Pelizzo MR \& Rugge M 2007 Primary squamous cell carcinoma of the thyroid: immunohistochemical profile and literature review. Tumori 93 518-521. (https://doi. org/10.1177/030089160709300522)

Gage H, Hubbard E \& Nodit L 2016 Multiple squamous cells in thyroid fine needle aspiration: friends or foes? Diagnostic Cytopathology $\mathbf{4 4}$ 676-681. (https://doi.org/10.1002/dc.23512)

Goldman RL 1964 Primary squamous cell carcinoma of the thyroid gland: report of a case and review of the literature. American Surgeon 30 247-252.

Gu H, Sui S, Cui X, Han B, Zhang C, Qi M, Li C \& Liu Z 2018 Thyroid carcinoma producing $\beta$-human chorionic gonadotropin shows different clinical behavior. Pathology International 68 207-213. (https://doi.org/10.1111/pin.12639)

Harada T, Katagiri M, Tsukayama C, Higashi Y \& Shimaoka K 1989 Squamous cell carcinoma with cyst of the thyroid. Journal of Surgical Oncology 42 136-143. (https://doi.org/10.1002/ jso.2930420214)

Hedinger C, Williams ED \& Sobin LH 1993 Other carcinomas. In World Health Organization International Histological Classification of Tumours: Histological Typing of Thyroid Tumours, 2nd ed., pp. 14-15. Eds C Hedinger, ED Williams \& LH Sobin. Berlin, Germany: Springer-Verlag.

Huang TY \& Assor D 1971 Primary squamous cell carcinoma of the thyroid gland: a report of four cases. American Journal of Clinical Pathology 55 93-98. (https://doi.org/10.1093/ajcp/55.1.93)

Huang TY \& Lin SG 1986 Primary squamous cell carcinoma of the thyroid. Indiana Medicine 79 763-764.

Hvilsom GB, Londero SC, Hahn CH, Schytte S, Pedersen HB, Christiansen P, Kiss K, Larsen SR, Jespersen ML, Lelkaitis G, et al. 2018 Anaplastic thyroid carcinoma in Denmark 1996-2012: a national prospective study of 219 patients. Cancer Epidemiology 53 65-71. (https://doi.org/10.1016/j.canep.2018.01.011)

Ibrahim MI, Jusoh YR, Adam NN \& Mohamad I 2018 Primary squamous cell carcinoma of the thyroid gland. Iranian Journal of Otorhinolaryngology 30 65-68.

Iwai H, Ohno Y \& Aoki N 2004 Anaplastic thyroid carcinoma with humoral hypercalcemia of malignancy (HHM): an autopsy case report. Endocrine Journal 51 303-310. (https://doi.org/10.1507/ endocrj.51.303)

Jang JY, Kwon KW, Kim SW \& Youn I 2014 Primary squamous cell carcinoma of thyroid gland with local recurrence: ultrasonographic and computed tomographic findings. Ultrasonography 33 143-148. (https://doi.org/10.14366/usg.13022)

Jones JM, McCluggage WG \& Russell CF 2000 Primary squamous carcinoma of the thyroid. Ulster Medical Journal 69 58-60.

Kakudo K, Bai Y, Ozaki T, Homma K, Ito Y \& Miyauchi A 2013 Intrathyroid epithelial thymoma (ITET) and carcinoma showing thymus-like differentiation (CASTLE):CD5-positive neoplasms (c) 2020 Society for Endocrinology Published by Bioscientifica Ltd. Printed in Great Britain 
mimicking squamous cell carcinoma of the thyroid. Histology and Histopathology 28 543-556. (https://doi.org/10.14670/HH-28.543)

Kampsen EB, Jager N \& Max MH 1977 Squamous cell carcinoma of the thyroid: a report of two cases. Journal of Surgical Oncology 9 567-578. (https://doi.org/10.1002/jso.2930090607)

Kaneko N, Kawano S, Matsubara R, Goto Y, Jinno T, Maruse Y, Sakamoto T, Hashiguchi Y, Iida M \& Nakamura S 2016 Tongue squamous cell carcinoma producing both parathyroid hormonerelated protein and granulocyte colony-stimulating factor: a case report and literature review. World Journal of Surgical Oncology 14 161. (https://doi.org/10.1186/s12957-016-0918-1)

Kang K, Park JH, Ryu JY, Lee SY, Ko GJ \& Kwon YJ 2013 Acute pyelonephritis with anaplastic thyroid carcinoma producing granulocyte colony-stimulating factor. Blood Research 48 63-66. (https://doi.org/10.5045/br.2013.48.1.63)

Kao NH, Tan CS \& Koh AJH 2019 The utility of immunohistochemistry in differentiating metastatic primary squamous cell carcinoma of the thyroid from a primary lung squamous cell carcinoma. Case Reports in Endocrinology 2019 8641267. (https://doi.org/10.1155/2019/8641267)

Kapoor VK, Sharma D, Mukhopadhyay AK \& Chattopadhyay TK 1985 Primary squamous cell carcinoma of the thyroid gland - a case report. Japanese Journal of Surgery 15 60-62. (https://doi.org/10.1007/ bf02469859)

Kasem K \& Lam AK 2020 Immunohistochemistry for protein detection in oesophageal squamous cell carcinoma. Methods in Molecular Biology 2129 279-294. (https://doi.org/10.1007/978-1-0716-03772_21)

Kaufmann O, Fietze E, Mengs J \& Dietel M 2001 Value of p63 and cytokeratin 5/6 as immunohistochemical markers for the differential diagnosis of poorly differentiated and undifferentiated carcinomas. American Journal of Clinical Pathology 116 823-830. (https://doi. org/10.1309/21TW-2NDG-JRK4-PFJX)

Kleer CG, Giordano TJ \& Merino MJ 2000 Squamous cell carcinoma of the thyroid: an aggressive tumor associated with tall cell variant of papillary thyroid carcinoma. Modern Pathology 13 742-746. (https:// doi.org/10.1038/modpathol.3880129)

Ko YS, Hwang TS, Han HS, Lim SD, Kim WS \& Oh SY 2012 Primary pure squamous cell carcinoma of the thyroid: report and histogenic consideration of a case involving a BRAF mutation. Pathology International 62 43-48. (https://doi. org/10.1111/j.1440-1827.2011.02745.x)

Korovin GS, Kuriloff DB, Cho HT \& Sobol SM 1989 Squamous cell carcinoma of the thyroid: a diagnostic dilemma. Annals of Otology, Rhinology, and Laryngology 98 59-65. (https://doi. org/10.1177/000348948909800113)

Koyama S, Fujiwara K, Nosaka K, Fukuhara T, Morisaki T, Miyake N, Kitano H \& Takeuchi H 2018 Immunohistochemical features of primary pure squamous cell carcinoma in the thyroid: an autopsy case. Case Reports in Oncology 11 418-424. (https://doi. org/10.1159/000490410)

Kukreti SC, Prabhune PV, Upadhyaya GH \& Shah HH 1972 Primary squamous cell carcinoma of the thyroid gland. Journal of the Indian Medical Association 58 287-288.

Kumar PV, Malekhusseini SA \& Talei AR 1999 Primary squamous cell carcinoma of the thyroid diagnosed by fine needle aspiration cytology: a report of two cases. Acta Cytologica 43 659-662. (https:// doi.org/10.1159/000331162)

Lai WA, Hang JF, Liu CY, Bai Y, Liu Z, Gu H, Hong S, Pyo JY, Jung CK, Kakudo K, et al. 2020 PAX8 expression in anaplastic thyroid carcinoma is less than those reported in early studies: a multiinstitutional study of 182 cases using the monoclonal antibody MRQ-50. Virchows Archiv 476 431-437. (https://doi.org/10.1007/ s00428-019-02708-4)

Lam AK 2017 Pathology of endocrine tumors update: World Health Organization new classification 2017-other thyroid tumors. AJSP: Reviews and Reports 22 209-216.
Lam AK \& Fridman M 2018 Characteristics of cribriform morular variant of papillary thyroid carcinoma in post-Chernobyl affected region. Human Pathology 74 170-177. (https://doi.org/10.1016/j. humpath.2018.01.006)

Lam KY \& Lo CY 1998 Metastatic tumors of the thyroid gland: a study of 79 cases in Chinese patients. Archives of Pathology and Laboratory Medicine 122 37-41.

Lam AK \& Lo CY 2006 Diffuse sclerosing variant of papillary carcinoma of the thyroid: a 35-year comparative study at a single institution. Annals of Surgical Oncology 13 176-181. (https://doi.org/10.1245/ ASO.2006.03.062)

Lam KY \& Sakamoto A 2004 Squamous cell carcinoma. In World Health Organization Classification of Tumours: Pathology and Genetics Tumours of Endocrine Organs, 3rd ed., p. 81. Eds RA DeLellis, RV Lloyd, PU Heitz \& C Eng. Lyon, France: IARC Press.

Lam AK \& Saremi N 2017 Cribriform-morular variant of papillary thyroid carcinoma: a distinctive type of thyroid cancer. EndocrineRelated Cancer 24 R109-R121. (https://doi.org/10.1530/ERC-170014)

Lam KY \& Yuen AP 1996 Cancer of the larynx in Hong Kong: a clinicopathological study. European Journal of Surgical Oncology 22 166-170. (https://doi.org/10.1016/s0748-7983(96)90749-0)

Lam KY, Law S, Tin L, Tung PH \& Wong J 1999a The clinicopathological significance of p21 and p53 expression in esophageal squamous cell carcinoma: an analysis of 153 patients. American Journal of Gastroenterology 94 2060-2068. (https://doi. org/10.1111/j.1572-0241.1999.01278.x)

Lam KY, Lo CY, Kwong DL, Lee J \& Srivastava G $1999 b$ Malignant lymphoma of the thyroid: a 30-year clinicopathologic experience and an evaluation of the presence of Epstein-Barr virus. American Journal of Clinical Pathology 112 263-270. (https://doi.org/10.1093/ ajcp/112.2.263)

Lam KY, Lo CY, Chan KW \& Wan KY 2000 Insular and anaplastic carcinoma of the thyroid: a 45-year comparative study at a single institution and a review of the significance of p53 and p21. Annals of Surgery 231 329-338. (https://doi.org/10.1097/00000658200003000-00005)

Lam KY, Lo CY \& Liu MC 2001a Primary squamous cell carcinoma of the thyroid gland: an entity with aggressive clinical behaviour and distinctive cytokeratin expression profiles. Histopathology 39 279-286. (https://doi.org/10.1046/j.1365-2559.2001.01207.x)

Lam KY, Lui MC \& Lo CY $2001 b$ Cytokeratin expression profiles in thyroid carcinomas. European Journal of Surgical Oncology 27 631-635. (https://doi.org/10.1053/ejso.2001.1203)

Lam AK, Lo CY \& Lam KSL 2005 Papillary carcinoma of thyroid: a 30-year clinicopathological review of the histological variants. Endocrine Pathology 16 323-330. (https://doi.org/10.1385/ ep:16:4:323)

Lam AK, Ong K \& Ho YH 2008 hTERT expression in colorectal adenocarcinoma: correlations with p21, p53 expressions and clinicopathological features. International Journal of Colorectal Disease 23 587-594. (https://doi.org/10.1007/s00384-008-0455-7)

Le QV, Ngo DQ \& Ngo QX 2019 Primary mucoepidermoid carcinoma of the thyroid: a report of a rare case with bone metastasis and review of the literature. Case Reports in Oncology 12 248-259. (https://doi. org/10.1159/000498917)

Lee JR, Vohman MD \& Pendergrast WJ 1980 Squamous cell carcinoma of the thyroid gland. Journal of the Medical Association of Georgia 69 755-758.

Lee JI, Chung YJ \& Lee SY 2013 Papillary thyroid carcinoma recurring as squamous cell carcinoma 10 years after total thyroidectomy: lessons from rapidly progressive papillary thyroid carcinoma. Internal Medicine 52 1593-1597. (https://doi.org/10.2169/ internalmedicine.52.9310)

Lichiardopol C, Şurlin V, Foarfă MC, Ghiluşi MC \& Bondari S 2016 Primary squamous cell carcinoma of the thyroid: a case report. https://erc bioscientifica com

https://doi.org/10.1530/ERC-20-0045
C) 2020 Society for Endocrinology Published by Bioscientifica Ltd. Printed in Great Britain 
Romanian Journal of Morphology and Embryology 57 (Supplement) 831-836.

Limberg J, Ullmann TM, Stefanova D, Finnerty BM, Beninato T, Fahey 3rd TJ \& Zarnegar R 2020 Prognostic characteristics of primary squamous cell carcinoma of the thyroid: a national cancer database analysis. World Journal of Surgery 44 348-355. (https://doi. org/10.1007/s00268-019-05098-5)

LiVolsi VA, Albores-Saavedra J, Asa SL, Baloch ZW, Sobrinho-Simōes M, Wenig B, DeLellis RA, Cady B, Mazzaferri EL, Hay I, et al. 2004 Papillary carcinoma. In World Health Organization Classification of Tumours: Pathology and Genetics - Tumours of Endocrine Organs, 3rd ed., pp. 57-66. Eds RA DeLellis, RV Lloyd, PU Heitz \& C Eng. Lyon, France: IARC Press.

Lo CY, Lam KY \& Wan KY 1999 Anaplastic carcinoma of the thyroid. American Journal of Surgery 177 337-339. (https://doi.org/10.1016/ s0002-9610(99)00052-5)

Long JL, Strocker AM, Wang MB \& Blackwell KE 2009 EGFR expression in primary squamous cell carcinoma of the thyroid. Laryngoscope 119 89-90. (https://doi.org/10.1002/lary.20062)

Long KB, Srivastava A, Hirsch MS \& Hornick JL 2010 PAX8 expression in well-differentiated pancreatic endocrine tumors: correlation with clinicopathologic features and comparison with gastrointestinal and pulmonary carcinoid tumors. American Journal of Surgical Pathology 34 723-729. (https://doi.org/10.1097/PAS.0b013e3181da0a20)

Makay O, Kaya T, Ertan Y, Icoz G, Akyildiz M, Yilmaz M, Tuncyurek M \& Yetkin E 2008 Primary squamous cell carcinoma of the thyroid: report of three cases. Endocrine Journal 55 359-364. (https://doi. org/10.1507/endocrj.k07e-102)

Misonou J, Aizawa M, Kanda M, Uekita Y \& Motohara T 1988 Pure squamous cell carcinoma of the thyroid gland - report of an autopsy case and review of the literature. Japanese Journal of Surgery 18 469-474. (https://doi.org/10.1007/bf02471475)

Molinaro E, Romei C, Biagini A, Sabini E, Agate L, Mazzeo S, Materazzi G, Sellari-Franceschini S, Ribechini A, Torregrossa L, et al. 2017 Anaplastic thyroid carcinoma: from clinicopathology to genetics and advanced therapies. Nature Reviews: Endocrinology 13 644-660. (https://doi.org/10.1038/nrendo.2017.76)

Molnár C, Molnár S, Bedekovics J, Mokánszki A, Győry F, Nagy E \& Méhes G 2019Thyroid carcinoma coexisting with Hashimoto's thyreoiditis: clinicopathological and molecular characteristics clue up pathogenesis. Pathology Oncology Research 25 1191-1197. (https:// doi.org/10.1007/s12253-019-00580-w)

Müssig K, Dahm J, Koitschev A, Horger M, Müller M, Bares R \& Wehrmann M 2008 Primary squamous cell carcinoma of the thyroid. Internal Medicine Journal 38 69-70. (https://doi. org/10.1111/j.1445-5994.2007.01569.x)

Nakhjavani M, Gharib H, Goellner JR \& Heerden JA 1999 Direct extension of malignant lesions to the thyroid gland from adjacent organs: report of 17 cases. Endocrine Practice 5 69-71. (https://doi. org/10.4158/EP.5.2.69)

Ng HY, Li J, Tao L, Lam AK, Chan KW, Ko JMY, Yu VZ, Wong M, Li B \& Lung ML 2018 Chemotherapeutic treatments increase PD-L1 expression in esophageal squamous cell carcinoma through EGFR/ ERK activation. Translational Oncology 11 1323-1333. (https://doi. org/10.1016/j.tranon.2018.08.005)

Ng JY, Lu CT \& Lam AK 2019 BRAF mutation: current and future clinical pathological applications in colorectal carcinoma. Histology and Histopathology 34 469-477. (https://doi.org/10.14670/HH-18-079)

Pakneshan S, Salajegheh A, Smith RA \& Lam AK 2013 Clinicopathological relevance of BRAF mutations in human cancer. Pathology 45 346-356. (https://doi.org/10.1097/ PAT.0b013e328360b61d)

Pillai S, Gopalan V, Smith RA \& Lam AK 2015 Diffuse sclerosing variant of papillary thyroid carcinoma - an update of its clinicopathological features and molecular biology. Critical Reviews in Oncology/
Hematology 94 64-73. (https://doi.org/10.1016/j. critrevonc.2014.12.001)

Prakash A, Kukreti SC \& Sharma MP 1968 Primary squamous cell carcinoma of the thyroid gland. International Surgery 50 538-541.

Raggio B, Barr J, Ghandour Z \& Friedlander P 2019 Primary squamous cell carcinoma of the thyroid. Ochsner Journal 19 290-292. (https:// doi.org/10.31486/toj.18.0002)

Rahman MA, Salajegheh A, Smith RA \& Lam AK 2014 BRAF inhibitor therapy for melanoma, thyroid and colorectal cancers: development of resistance and future prospects. Current Cancer Drug Targets 14 128-143. (https://doi.org/10.2174/1568009614666140121150930)

Rahman MA, Salajegheh A, Smith RA \& Lam AK 2015 Multiple proliferation-survival signalling pathways are simultaneously active in BRAF V600E mutated thyroid carcinomas. Experimental and Molecular Pathology 99 492-497. (https://doi.org/10.1016/j. yexmp.2015.09.006)

Rausch T, Benhattar J, Sutter M \& Andrejevic-Blant S 2010 Thyroid carcinoma with papillary and squamous features: report of a case with histogenetic considerations. Pathology, Research and Practice 206 263-269. (https://doi.org/10.1016/j.prp.2009.05.003)

Riddle PE \& Dincsoy HP 1987 Primary squamous cell carcinoma of the thyroid associated with leukocytosis and hypercalcemia. Archives of Pathology and Laboratory Medicine 111 373-374.

Roeder CA 1921 Squamous-cell epithelioma of the thyroid. Annals of Surgery 73 23-29. (https://doi.org/10.1097/00000658-192101000-00005)

Rosa M \& Toronczyk K 2012 Fine needle aspiration biopsy of three cases of squamous cell carcinoma presenting as a thyroid mass: cytological findings and differential diagnosis. Cytopathology 23 45-49. (https:// doi.org/10.1111/j.1365-2303.2010.00828.x)

Rosai J, Albores-Saavedra J, Asioli S, Baloch ZW, Bogdanova T, Chen H, DeLellis RA, Erikson LA, Fagin JA, Franssila KO, et al. 2017 Papillary thyroid carcinoma. In WHO Classification of Tumours of Endocrine Organs, 4th ed., pp. 81-91. Eds RV Lloyd, RY Osamura, G Koppel \& J Rosai. Lyon, France: IARC Press.

Rupani A, Hughes OR, Watkinson J, Nutting CM \& Thway K 2017 Metastatic papillary thyroid carcinoma with adjacent BRAF (V600E)mutated squamous cell carcinoma. International Journal of Surgical Pathology 25 243-245. (https://doi.org/10.1177/1066896916674811)

Sahoo M, Bal CS \& Bhatnagar D 2002 Primary squamous-cell carcinoma of the thyroid gland: new evidence in support of follicular epithelial cell origin. Diagnostic Cytopathology 27 227-231. (https://doi. org/10.1002/dc.10178)

Saito K, Kuratomi Y, Yamamoto K, Saito T, Kuzuya T, Yoshida S, Moriyama SI \& Takahashi A 1981 Primary squamous cell carcinoma of the thyroid associated with marked leukocytosis and hypercalcemia. Cancer 48 2080-2083. (https://doi.org/10.1002/10970142(19811101)48:9<2080::aid-cncr2820480927>3.0.co;2-n)

Sanchez-Sosa S, Rios-Luna NP, Tamayo Bdel Bdel R, Simpson K \& Albores-Saavedra J 2006 Primary squamous cell carcinoma of the thyroid arising in Hashimoto's thyroiditis in an adolescent. Pediatric and Developmental Pathology 9 496-500. (https://doi.org/10.2350/0604-0073.1)

Sapalidis K, Anastasiadis I, Panteli N, Strati TM, Liavas L, Poulios C \& Kanellos I 2014 Primary squamous cell carcinoma of the thyroid gland. Journal of Surgical Case Reports. 2014 rju133. (https://doi. org/10.1093/jscr/rju133)

Sarda AK, Bal S, Arunabh SMK, Singh MK \& Kapur MM 1988 Squamous cell carcinoma of the thyroid. Journal of Surgical Oncology 39 175-178. (https://doi.org/10.1002/jso.2930390308)

Segal K, Sidi J, Abraham A, Konichezky M \& Ben-Bassat M 1984 Pure squamous cell carcinoma and mixed adenosquamous cell carcinoma of the thyroid gland. Head and Neck Surgery 6 1035-1042. (https:// doi.org/10.1002/hed.2890060610)

Shah AA, La Fortune K, Miller C, Mills SE, Baloch Z, LiVolsi V, Dacic S, Mahaffey AL, Nikiforova M, Nikiforov YE, et al. 2017 Thyroid (c) 2020 Society for Endocrinology Published by Bioscientifica Ltd. Printed in Great Britain 
sclerosing mucoepidermoid carcinoma with eosinophilia: a clinicopathologic and molecular analysis of a distinct entity. Modern Pathology 30 329-339. (https://doi.org/10.1038/modpathol.2016.180)

Shimaoka K \& Tsukada Y 1980 Squamous cell carcinomas and adenosquamous carcinomas originating from the thyroid gland. Cancer 46 1833-1842. (https://doi.org/10.1002/1097. 0142(19801015)46:8<1833::aid-cncr2820460822>3.0.co;2-g)

Shrestha M, Sridhara SK, Leo LJ, Coppit 3rd GL \& Ehrhardt NM 2013 Primary squamous cell carcinoma of the thyroid gland: a case report and review. Head and Neck 35 E299-E303. (https://doi.org/10.1002/ hed.23152)

Simpson WJ \& Carruthers J 1988 Squamous cell carcinoma of the thyroid gland. American Journal of Surgery 156 44-46. (https://doi. org/10.1016/s0002-9610(88)80169-7)

Struller F, Senne M, Falch C, Kirschniak A, Konigsrainer A \& Muller S 2017 Primary squamous cell carcinoma of the thyroid: case report and systematic review of the literature. International Journal of Surgery Case Reports 37 36-40. (https://doi.org/10.1016/j.ijscr.2017.06.011)

Suzuki A, Hirokawa M, Takada N, Higuchi M, Tanaka A, Hayashi T, Kuma S \& Miyauchi A 2018 Utility of monoclonal PAX8 antibody for distinguishing intrathyroid thymic carcinoma from follicular cellderived thyroid carcinoma. Endocrine Journal 65 1171-1175. (https:// doi.org/10.1507/endocrj.EJ18-0282)

Theander C, Lödén B, Berglund J \& Seidal T 1993 Primary squamous carcinoma of the thyroid - a case report. Journal of Laryngology and Otology 107 1155-1158. (https://doi.org/10.1017/s002221510012554x)

Tomas A, Futter CE \& Eden ER 2014 EGF receptor trafficking: consequences for signaling and cancer. Trends in Cell Biology $\mathbf{2 4}$ 26-34. (https://doi.org/10.1016/j.tcb.2013.11.002)

Tsuchiya A, Suzuki S, Nomizu T, Yamaki Y, Abe R \& Katayama S 1990 Squamous cell carcinoma of the thyroid - a report of three cases. Japanese Journal of Surgery 20 341-345. (https://doi.org/10.1007/ bf02470671)

Ulisse S, Tuccilli C, Sorrenti S, Antonelli A, Fallahi P, D'Armiento E, Catania A, Tartaglia F, Amabile MI, Giacomelli L, et al. 2019 PD-1 ligand expression in epithelial thyroid cancers: potential clinical implications. International Journal of Molecular Sciences 20 E1405. (https://doi.org/10.3390/ijms20061405)

Varlı B, Taşkın S \& Ortaç F 2019 Metastatic cervical carcinoma to the thyroid gland: a rare diagnosis. Taiwanese Journal of Obstetrics and Gynecology 58 298-299. (https://doi.org/10.1016/j.tjog.2019.01.024)
Vatsyayan A, Mandlik D, Patel P, Patel P, Sharma N, Joshipura A, Patel M, Odedra P, Dubbal JC, Shah DS, et al. 2019 Metastasis of squamous cell carcinoma of the head and neck to the thyroid: a single institution's experience with a review of relevant publications. British Journal of Oral and Maxillofacial Surgery 57 609-615. (https:// doi.org/10.1016/j.bjoms.2019.05.012)

Vico P, Delcorde A, Rahier I, Treille de Grandsaigne S, Famaey JP \& Body JJ 1992 Hypertrophic osteoarthropathy and thyroid cancer. Journal of Rheumatology 19 1153-1156.

Wan Muhaizan WM, Phang KS, Sharifah NA \& al Amin D 1998 Primary squamous cell carcinoma of the thyroid - a case report. Malaysian Journal of Pathology 20 109-111.

Wygoda A, Rutkowski T, Szcześniak-Kłusek B, Mrochem-Kwarciak J, Jędrzejewska M \& Składowski K 2017 Primary squamous-cell thyroid carcinoma - a successful treatment with five-year follow-up. Endokrynologia Polska 68 592-596. (https://doi.org/10.5603/EP. a2017.0048)

Yang S, Li C, Shi X, Ma B, Xu W, Jiang H, Liu W, Ji Q \& Wang Y 2019 Primary squamous cell carcinoma in the thyroid gland: a population-based analysis using the SEER database. World Journal of Surgery 43 1249-1255. (https://doi.org/10.1007/s00268-019. 04906-2)

Yasumatsu R, Sato M, Uchi R, Nakano T, Hashimoto K, Kogo R, Taura M, Matsuo M, Nakashima T \& Nakagawa T 2018 The treatment and outcome analysis of primary squamous cell carcinoma of the thyroid. Auris, Nasus, Larynx 45 553-557. (https://doi.org/10.1016/j. anl.2017.07.009)

Yazawa S, Toshimori H, Nakatsuru K, Katakami H, Takemura J \& Matsukura S 1995 Thyroid anaplastic carcinoma producing granulocyte-colony-stimulating factor and parathyroid hormonerelated protein. Internal Medicine 34 584-588. (https://doi. org/10.2169/internalmedicine.34.584)

Yucel H, Schaper NC, van Beek M \& Bravenboer B 2010 Primary squamous cell carcinoma of the thyroid years after radioactive iodine treatment. Netherlands Journal of Medicine 68 224-226.

Zhou XH 2002 Primary squamous cell carcinoma of the thyroid. European Journal of Surgical Oncology 28 42-45. (https://doi. org/10.1053/ejso.2001.1180)

Zimmer PW, Wilson D \& Bell N 2003 Primary squamous cell carcinoma of the thyroid gland. Military Medicine 168 124-125. (https://doi. org/10.1093/milmed/168.2.124)

Received in final form 25 March 2020

Accepted 5 April 2020

Accepted Manuscript published online 6 April 2020 (c) 2020 Society for Endocrinology Published by Bioscientifica Ltd. Printed in Great Britain 